\title{
Letter from the Editors: Introducing the new FMEJ issue published by Springer Nature
}

\author{
Dragana Martinovic ${ }^{1 *}$ and Jérôme Proul $x^{2}$
}

\author{
*Correspondence: \\ dragana@uwindsor.ca \\ ${ }^{1}$ University of Windsor, \\ Windsor, ON, Canada \\ Full list of author information \\ is available at the end of the \\ article
}

Dear readers and contributors, as Editors-in-Chief we welcome you to a revamped issue of the Fields Mathematics Education Journal (FMEJ), and would like to inform you about some changes as well as to introduce you to the first issue published by Springer Nature.

We use this opportunity to thank Dona Kotsopoulos (Huron University College, London, $\mathrm{ON}$ ) for years of co-leading this journal. Donna was instrumental in starting this journal, but had to step down from the position because of increased leadership responsibilities at her new work place. Jérôme Proulx (Université du Québec à Montréal, Montréal, QC) has been nominated as new Editor-in-Chief and will replace Donna, working together with Dragana Martinovic (University of Windsor, Windsor, ON) to lead the new issues of FMEJ with Springer Nature.

As Editors-in-Chief, we have already mapped some new directions for the journal and will be happy to inform you about them before 2018, when we will start implementing them. To give you a glimpse of what these changes may be, we would like to extend the publication options in our journal by adding to research papers other forms of scholarship, such as theoretical papers and discussions. Some of these will be, as before, by submission, while some will be by invitation only. We will continue to be open to guestedited thematic issues. There will be also some changes in our Editorial Board, as we renew it every 3 years. So, stay tuned to read about these changes on the journal website and contact us if you have questions or suggestions.

In this issue, we present two research papers. Darja Kalajdzievska and Lindsay Wessel (University of Manitoba) were concerned about the failure and withdrawal rates in introductory post-secondary mathematics courses. To counteract this problem, they modified a course structure in a first-year undergraduate mathematics course, by providing students who did not progress as expected, opportunity to learn in smaller classes and with increased interaction and frequent feedback and scaffolding from the instructor. The results of their efforts are encouraging for post-secondary educators who share Darja's and Lindsay's concerns.

Second paper is written by Julie Smart and Sandra Linder (Clemson University). The authors describe the results of a 2-year study in which they developed, validated, and implemented the Elementary Mathematics Motivation Inventory. This instrument was designed to measure motivational constructs (i.e., mathematics anxiety; mathematics self-efficacy; and value of mathematics) related to numbers and operations content in

(c) The Author(s) 2017. This article is distributed under the terms of the Creative Commons Attribution 4.0 International License (http://creativecommons.org/licenses/by/4.0/), which permits unrestricted use, distribution, and reproduction in any medium, provided you give appropriate credit to the original author(s) and the source, provide a link to the Creative Commons license, and indicate if changes were made. 
elementary students. The results of this study show that the instrument may be useful for educators who are working with elementary school children, especially if the improvement focus is on numbers and operations.

With these two new papers, we thus enthusiastically launch the first issue of FMEJ with Springer Nature.

Dragana Martinovic and Jérôme Proulx, Editors-in-Chief.

November 14, 2017.

Authors' contributions

DM read the papers and wrote their summaries, DM and JP conceptualized changes for the journal and wrote the manuscript. Both authors read and approved the final manuscript.

Author details

${ }^{1}$ University of Windsor, Windsor, ON, Canada. ${ }^{2}$ Université du Québec à Montréal, Montreal, QC, Canada.

Competing interests

The authors declare that they have no competing interests.

\section{Publisher's Note}

Springer Nature remains neutral with regard to jurisdictional claims in published maps and institutional affiliations.

Received: 14 September 2017 Accepted: 16 October 2017

Published online: 08 December 2017

Submit your manuscript to a SpringerOpen ${ }^{\circ}$ journal and benefit from:

- Convenient online submission

- Rigorous peer review

- Open access: articles freely available online

- High visibility within the field

- Retaining the copyright to your article

Submit your next manuscript at $\gg$ springeropen.com 